\title{
Chapter 22:
}

\section{Institutional and legal challenges to realising clean and safe water for all in Uganda}

\section{Phiona Muhwezi Mpanga}

Water resources are one of the key natural resources slated to drive Uganda's economic progress from a least developed economy to middle-income status. ${ }^{1}$ In the country, water is important for a variety of uses: domestic, production, hydropower generation, and transport, among others. Uganda is not a water scarce country. It has both transboundary and internal water sources. The country's rivers and lakes, including wetlands, cover about $18 \%$ of the total surface area of the country. ${ }^{2}$ Uganda receives ample rainfall, which also enhances available water sources. ${ }^{3}$ The country's most significant hydrological features include Lake Victoria and the River Nile. ${ }^{4}$ Nearly all of Uganda lies within the River Nile basin which charts its course through eleven African countries, many of which are water scarce. ${ }^{5}$ Despite the fact that water is readily available, the realisation of the human right to water and sanitation has not been achieved, particularly for the most vulnerable sectors of the population. At the same time, Uganda has not escaped the effects of climate change, which threatens its freshwater resources. Within this context, it is appropriate to interrogate Uganda's institutional and legal framework of relevance to the provision of water and sanitation services in order to identify the opportunities and challenges that impede the realisation of the right to water and sanitation.

This chapter critiques the institutional framework governing water distribution, identifying the challenges, opportunities and prerequisites for establishing a sustainable water delivery system. It argues that while existing institutions have enhanced

1 Government of Uganda (2016: 4).

2 According to the Uganda Water Supply Atlas 2017, the country comprises a total area of $241,550 \mathrm{~km}^{2}$, of which $41,028 \mathrm{~km}^{2}$ are covered by fresh water bodies, permanent and seasonal swamps. See Government of Uganda (2017a).

3 See <http://www.nationsencyclopedia.com/Africa/Uganda-CLIMATE.html > (accessed 17-52018).

4 See $<$ http://countrystudies.us/uganda/18.htm.> (accessed 17-5-2018).

5 The river Nile basin area is shared by Burundi, Rwanda, Tanzania, DRC, Uganda, South Sudan, Sudan, Ethiopia, Eritrea, Kenya and Egypt. 
access to water and sanitation services, on the whole, there remains a deficit of unserved citizens. This may be due to the fragmentation of institutions and institutional mandates. It is argued that a radical shift from the operative legal and administrative mechanisms that are influenced by neoliberalism, to a more human rights-based system, would facilitate and meaningfully improve water and sanitation delivery to Ugandan citizens. The chapter attempts to draw linkages between the human rights and environmental discourse in order to identify impediments to achieving SDG 6 in Uganda, which calls for clean water and sanitation for all people by 2030 .

\section{The human right to water and sanitation}

The human right to water is defined as the "right of everyone to sufficient, safe, physically accessible and affordable water for personal and domestic uses". ${ }^{6}$ These constitute the five key elements of the human right to water and establish specific legal obligations for states parties to the International Covenant on Economic, Social and Cultural Rights (ICESCR). According to the United Nations Committee on Economic and Social Cultural Rights (UNCESCR), the right to water also includes freedoms and entitlements. The freedom pertains to the autonomy of access to water supply; and entitlement relates to water supply and management that provides the equality of opportunity for people to enjoy the right to water. ${ }^{7}$

Access to sufficient water is likely to pose a challenge to many individuals because of the high demand for water for production. It is clear that most industrial undertakings require huge amounts of water. For a developing country that hopes to hasten industrial development, it is of concern that ultimately, the demand for water for domestic consumption particularly for vulnerable citizens, will remain unmet.

Similarly, access to water of a quality that is safe for consumption remains a challenge when water sources are frequently flooded with sewage, chemical substances and radiological hazards contaminating the water available for domestic use. ${ }^{8}$ Research indicates that changes in groundwater levels substantially change the quality of water and changes in weather patterns have a negative impact on the quality of water delivered to citizens within the context of the World Health Organization's standards of quality. ${ }^{9}$ For instance, where long droughts have exhausted water resources, even where the infrastructure exists, it becomes difficult for a government to meet its obligation to deliver water to its citizens. In such instances, the right to physical access to

Bates (2008: 2). 
water services is inadvertently at risk due to the effects of climate change.$^{10}$ Further extreme weather events such as flash floods damage water infrastructure set up along rivers and lakes, posing a threat to the affordability of water services in many areas. ${ }^{11}$ The rise and fall of groundwater levels threaten the acceptability of water services delivered to citizens as it makes the colour and taste of water unacceptable to its intended users. ${ }^{12}$

Conversely, the enjoyment of a right to water and sanitation envisages a role for the state, which has obligations to respect, protect and fulfil the human rights of its citizens, including the right to water under international law. First, the right to water demands that states respect the right to water by refraining from acts that would cause unlawful pollution or contamination of water. ${ }^{13}$ Within this context, a state must take measures to ensure that access to water is not interfered with or denied unjustly.

Secondly, the obligation to protect the human right to water and sanitation enjoins state parties to adopt necessary and effective legislative measures to restrain third parties, including individuals, groups, corporations and their agents from inequitably dealing with water resources. ${ }^{14}$ Within this context, states must avert acts of third party water operators that are likely to compromise equality, affordability and physical accessibility of sufficient safe and acceptable water, by establishing an effective national regulatory system. Such a system should ideally include institutions that provide independent monitoring, a framework for genuine public participation and potential penalties for non-compliance on the part of water suppliers. ${ }^{15}$

The obligation to fulfil the right to water and sanitation entails facilitating, promoting and providing water. ${ }^{16}$ Access to information is an important aspect of the obligation to fulfil the right to water. To satisfy the requirement of accessibility of water resources, the state ought to enhance access to information. ${ }^{17}$ This entails ensuring that citizens are able to seek and receive information useful to enable them to make informed choices about water services. Conversely, the state ought to take steps to impart information concerning water issues to citizens.

10 For instance, see <http://theugandan.com.ug/exceptionally-dry-river-rwizi-leads-mbarara-water-warnings-nwsc/> (accessed 17-5-2018).

11 United Nations (2010: 3).

12 Ibid: 4.

13 Also refer to General Comment 14, para. 34; Bourquain (2008: 141-142); General Comment 15 para. 21; Mwebaza (2009); and Twinomugisha (2009).

14 General Comment 15, para. 23

15 General Comment 15, para. 24. Also see General Comment 14, para. 35 on the right to health which describes the obligation to protect to include equal access to health-related services provided by third parties. Bourquain (2008: 148).

16 General Comment 15, para. 25; and General Comment 14, para. 37.

17 General Comment 15, para. 12(c)(iv). 
3 An overview of the legislative and institutional framework pertaining to water and sanitation services in Uganda

Within the context of governance and the institutional framework, water and sanitation is a shared responsibility of the central government and local government. The local government is based on the district as the main administrative unit. The Constitution of the Republic of Uganda, 1995 (1995 Constitution) stipulates that: ${ }^{18}$

...the system of local government in Uganda shall be based on the district as a unit under which there shall be such local governments and administrative units as Parliament may by law provide.

Article 189 of the 1995 Constitution stipulates that the functions of the central government and other functions and services not specified in the sixth schedule are the responsibility of local governments; local district councils are mandated to execute water and sanitation services functions. To enable the functioning of local governments, the 1995 Constitution further provides that the applicable principles to the local government system shall include appropriate measures to enable local government units to plan, initiate and execute policies in respect of matters falling within their jurisdiction. ${ }^{19}$

In the exercise of its constitutional powers, the Parliament of Uganda is required to make laws on any matter for the development and good governance of the country. ${ }^{20}$ Objective XIV of the National Objectives and Directive Principles of State Policy (NODPSP) stipulates that: ${ }^{21}$

The State shall endeavour to fulfil the fundamental rights of all Ugandans to social justice and economic development and shall in particular, ensure that -

All Ugandans enjoy rights and opportunities and access to education, health services, clean and safe water, work, decent shelter, adequate clothing, food, security and pension and retirement benefits.

Objective XXI further stipulates that the state shall take all practical measures to promote a good water management system at all levels. ${ }^{22}$ Article 8A of the 1995 Constitution envisages that the state shall fulfil its obligations by enacting laws to give effect to the rights enumerated in the NODPSP. The bill of rights in the 1995 Constitution explicitly guarantees a right to a clean and healthy environment to all citizens.

There are three primary laws that directly impact on water delivery, supply and sanitation. These are the Water Act (and its attendant regulations), the National Water and Sewerage Corporation Act (NWSC Act) and the National Environment Act (NEA), all

18 Article 176(1) of the Constitution of Uganda, 1995.

19 Article 176(2)(e) of the Constitution of Uganda, 1995.

20 Article 79(1) of the Constitution of Uganda, 1995.

$21 \quad 1995$ Constitution.

22 Ibid. 
of which were promulgated in $1995 .{ }^{23}$ The Water Act, the NWSC Act and the NEA were promulgated pursuant to the 1995 Constitution, and as part of broader environmental protection reforms.

Two considerations provide an important background to the motivation behind these water and environmental law reforms. One is that prior to the enactment of these laws, principles regulating water resources and water delivery were scattered in several outdated and inadequate laws. ${ }^{24}$ The new legislation sought to harmonise the water regime bringing water resource management under one comprehansive law. Secondly, the state had ratified the Ramsar Convention relating to the protection of wetlands, but there was no domestic law protecting wetlands. ${ }^{25}$ Given the emphasis on environmental rights within the NODPSP and the main body of the 1995 Constitution, it would seem that at the time of promulgating the Constitution, its drafters were more intent on articulating principles for the protection and management of the environment. ${ }^{26}$ The above neither underscored strengthening the water management institutions as a vehicle for improving water and sanitation services delivery within an inclusive model, nor did they envision propagating a rights-based approach to water delivery. Given that the constitutional protection of socio-economic rights typically enhances their enforcement by other State institutions, the failure to explicitly spell out the nature and scope of a right to water and sanitation within the 1995 Constitution was reflected in subsequent statutes enacted by Parliament, after its promulgation. ${ }^{27}$ Four examples are provided below to demonstrate this.

First, the conceptualisation of water and sanitation services within Uganda's water regime remains problematic. The term 'water' is defined by the Water Act as including: ${ }^{28}$

(i) Water flowing or situated upon the surface of any land;

(ii) Water flowing or contained in-

(A) Any river, stream, watercourse or other natural course for water;

(B) Any lake, pan, swamp, marsh or spring, whether or not it has been altered or artificially improved;

(iii) Ground water;

(iv) Such other water as the Ministry may from time to time declare to be water.

As a result, water that is subject to the Water Act regulatory framework appears to be slightly different from that conceptualised within the context of international human

23 The Water Act (Chapter 152, Laws of Uganda) and the NWSC Act (Chapter 317, Laws of Uganda) were promulgated in 1995. The former commenced in 1997 and the latter in 1995.

24 Water service delivery was governed by NWSC Decree, 34 of 1972. Water management was governed through Public Lands Act 1969 and Rivers Act, Chapter 357, 1907.

25 Uganda acceded to the Ramsar Convention in March 1988.

26 At about the same time that the Water Act and NWSC Act were promulgated, Parliament also promulgated the NEA (Chapter 153, Laws of Uganda) in 1995.

27 Mpanga (2015: 164).

28 Section 1 of the Water Act. 
rights law, the UNCESCR's General Comment 15 and SDG 6. In the author's view, while this definition suits an understanding of water resources within the environmental law context of conservation and management, it does not aptly contemplate 'water' within the context of a right to access clean and safe water for domestic use. As mentioned above, it is important to conceptualise water rights within the dual context of environmental and human rights law.

Historically, access to water, particularly in rural areas and non-serviced urban areas, was based on customary practices. This meant that those within the precincts of a spring or well would simply collect water from this source without necessarily seeking permission or consent. The Water Act maintains customary rights to water. ${ }^{29}$ To this end, it stipulates that: ${ }^{30}$

... a person may -

(a) while temporarily at any place; or

(b) being the occupier of or a resident on any land, where there is a natural source of water use that water for domestic use, fighting fire or irrigating a subsistence garden.

Beyond the customary right to access water, the Water Act also embraces the international law understanding of a right to water set out in the General Comment 15 and referred to earlier in this chapter. First, the Act has as one of several objectives, "to promote the provision of a clean, safe and sufficient supply of water for domestic purposes to all persons". ${ }^{31}$

Second, within the context of addressing rights and freedoms to water and sanitation, the Water Act stipulates that: ${ }^{32}$

$\ldots$ the occupier of land or resident on land may, with the approval of the authority responsible for the area, use any water under the land occupied by him or her on which he or she is resident or any land adjacent to that land.

In relation to sewerage services, the Water Act stipulates that a sewerage authority may "connect any land to its works on application by the owner or his or her agent, in a form prescribed by regulation or the authority". ${ }^{33}$ Such an application cannot be

29 Customary rights to water refer to the traditional understanding that natural water sources on land can be impliedly accessed by any member of the community.

30 Section 7(1)(a) and (b) of the Water Act.

31 Section 4(b) of the Water Act. Under the definition contained in Section (1), 'domestic use' includes, use for the purpose of human consumption, washing and cooking by persons ordinarily resident on the land where the use occurs; watering not more than 30 livestock units; irrigating a subsistence garden; and watering a subsistence fish pond.

32 Section 7(2) of the Water Act. Domestic use is defined in Section 1(1) of the Water Act in substantially the same manner as General Comment 15 . It includes purposes of human consumption, washing and cooking by persons ordinarily resident on the land where the use occurs; watering not more than 30 livestock units; irrigating a subsistence garden; and watering a subsistence pond.

33 Section $63(3)(b)$ of the Water Act. 
unreasonably rejected. Where a private sewerage connection is more appropriate, the Water Act stipulates that: ${ }^{34}$

(1) A person who wishes -

(a) to construct a private sewer within that sewerage area; or

(b) to connect a private sewer to the authority's sewer,

may apply to the relevant sewerage authority in a manner prescribed by regulations or the authority.

While the Water Act goes to great lengths to promote the standards through which water can be maintained in a clean and safe state, through regulating who and how water can be abstracted, the Act does not explicitly grant citizens a right to access water services. The statutory right relating to access to sewerage services is far more explicit than any provision relating to water services.

On the other hand, when analysed through the context of state responsibility to realise the rights to water and sanitation, it would seem to fall short. The Water Act stipulates that: "All rights to investigate, control, protect and manage water in Uganda for any use is vested in the Government...". ${ }^{35}$ Even though the content of the Water Act goes so far as to set out explicit statutory provisions relating to the respect and protection of the right. It spells out very little about the promotion and fulfilment of the right in concrete terms.

Third, it should be noted that within the context of a sound institutional framework, the legal and policy framework establishes various institutions that appear to remove power from local government. ${ }^{36}$ Given that the constitutional provisions relate to decentralising water and sanitation service delivery, it is arguable that the establishment of these institutions may be problematic when viewed from this perspective.

The Water Act establishes several structures that are responsible for the investigation, use, control, protection, management or administration of water resources. Section 43 envisages that the minister responsible for water will exercise his or her powers and functions with regard to the objectives of the Act; any relevant international agreements regulating the use of water to which Uganda is a party, and any policy of government concerning decentralisation of powers and functions.

The Water Act elaborates the institutional framework within which water is supplied. ${ }^{37}$ For instance, the Act envisages the creation of water supply areas delineated along local government borders. The local governments that constitute water supply areas, are required to establish water supply authorities, and it is these water supply authorities that are ultimately mandated to deliver water to households. ${ }^{38}$ In urban

34 Section 65 of the Water Act.

35 Section 5 of the Water Act.

36 Section 16 of the NEA; Government of Uganda (2012: 4); and Nabaho (2013).

37 Sections $45-61$ of the Water Act.

38 Section 45 and 46 of the Water Act. In reality this chain of supply applies to a fraction of the population, $69 \%$ in urban areas and $64 \%$ in rural areas. The rest of the population rely on 
areas, the water supply authority is the NWSC, while in rural areas, the mandate is held by the local government or municipal council. ${ }^{39}$ Umbrella organisations have also been gazetted as water authorities. ${ }^{40}$

The Water Act sets out the various institutions for planning and managing water resources. The Water Policy Committee established under the Act is responsible for planning for water resource management nationally. At lower levels, local governments are mandated to make plans for the delivery of water services in their respective districts. The Act also establishes water user associations and water supply and sanitation boards where water is sourced from boreholes, wells and springs or piped water schemes respectively. ${ }^{41}$ From the foregoing, it is clear that the Water Act seeks to shift from a national to a local government based water delivery system and creates an institutional set up to support the shift.

There are several agencies that deal with the different components of water as defined above that include: the Ministry of Water and Environment as the parent agency; with the Directorate for Water Development, Water Resources Management; semiautonomous agencies such as NWSC and the National Environment Management Agency (NEMA). In practice, management and conservation aspects have conflicted with urgent demands for water supply. It can be argued that the institutional framework does not appropriately synthesise human rights and environmental law principles through which the right to water for consumption may be universally enjoyed by citizens.

As part of the strategy to improve access, the water sector established several institutions responsible for water services, namely: the Ministry of Water and Environment units (Directorates); private water operators; six umbrella organisations; four water management zones and 15 catchment management organisations; and water and sanitation development facilities at the regional level. ${ }^{42}$ Each of these institutions has been established to serve a specific purpose within the strategic goals prescribed by the Ministry as indicated in table 1 below. The Directorates are established to play a strategic role in the actual implementation of the programs. The umbrella organisations support the local water authorities to improve their functionality in terms of promoting the delivery of water services' ensuring the financial viability of projects and promoting the sustainability of projects. ${ }^{43}$ The water and sanitation development facilities were established to bring services closer to the target communities and ensure

naturally existing water sources and do not benefit from the efficient quality control mechanisms available to those who access piped water supply. Government of Uganda (2013: 1 and 11).

Within the capital city, Kampala Capital City Authority Act mandates the institution to take responsibility for public water sources and public sanitation services.

40 Gazette of 14 July 2017 in Vol. CX No. 39, General Notices No. 577-582.

41 Sections 50 and 51 of the Water Act.

42 Government of Uganda (2017b).

43 Government of Uganda (2017b: 8). 
equitable distribution of resources within the decentralised framework. ${ }^{44}$ The water management zones were created to ensure that water resources are managed more broadly beyond the administrative structures since many of the water resources are shared by more than one district. ${ }^{45}$ The catchment management organisations were designed to oversee and protect catchment areas that ultimately affect water resources. ${ }^{46}$ Finally, the private water operators provide water delivery services at the very lowest household-level, where piped schemes have been established. ${ }^{47}$

Table 1: Institutions in the water and sanitation sector ${ }^{48}$

\begin{tabular}{|c|c|c|c|}
\hline Institution & $\begin{array}{l}\text { Number of } \\
\text { structures }\end{array}$ & Names of structures & Institutional Mandate \\
\hline $\begin{array}{l}\text { Directorates within } \\
\text { the Ministry of Water } \\
\text { and Environment }\end{array}$ & 2 & $\begin{array}{l}\text { Directorate of Water } \\
\text { Resources Management. } \\
\text { Directorate for Water } \\
\text { Development }\end{array}$ & $\begin{array}{l}\text { Managing and developing } \\
\text { water resources of Uganda in } \\
\text { an integrated and sustainable } \\
\text { manner in order to provide } \\
\text { water of adequate quantity } \\
\text { and quality. } \\
\text { Overall technical oversight } \\
\text { for planning, implementing } \\
\text { of delivery of urban, rural } \\
\text { water and sanitation services. }\end{array}$ \\
\hline $\begin{array}{l}\text { Semi-autonomous } \\
\text { agencies }\end{array}$ & 2 & $\begin{array}{l}\text { National Water and } \\
\text { Sewerage Corporation; } \\
\text { National Environment } \\
\text { Management Authority }\end{array}$ & $\begin{array}{l}\text { Water supply and sanitation } \\
\text { across the country. } \\
\text { Coordinating, monitoring, } \\
\text { regulating and supervising } \\
\text { environmental management } \\
\text { in the country. }\end{array}$ \\
\hline $\begin{array}{l}\text { Water \& Sanitation } \\
\text { Development Facility }\end{array}$ & 4 & $\begin{array}{l}\text { WSDF (North), WSDF } \\
\text { (East), WSDF (Central), } \\
\text { WSDF (Southwest) }\end{array}$ & $\begin{array}{l}\text { To bring services closer to } \\
\text { target communities and en- } \\
\text { sure equity in the decentralis- } \\
\text { ing process. }\end{array}$ \\
\hline $\begin{array}{ll}\text { Umbrella Organisa- } \\
\text { tions }\end{array}$ & 6 & $\begin{array}{l}\text { Southwest, Midwest, } \\
\text { Centre, North, East and } \\
\text { Karamoja }\end{array}$ & $\begin{array}{l}\text { Support the local water au- } \\
\text { thorities/ boards to improve } \\
\text { functionality, financial via- } \\
\text { bility and sustainability of } \\
\text { small piped water schemes. }\end{array}$ \\
\hline $\begin{array}{l}\text { Catchment manage- } \\
\text { ment organisations }\end{array}$ & 15 & & $\begin{array}{l}\text { To plan and implement plans } \\
\text { for the water management } \\
\text { zones. }\end{array}$ \\
\hline
\end{tabular}

The NWSC Act established the NWSC, whose mandate is primarily water and sanitation delivery in a commercial context. The Act stipulates that the objects of the NWSC

44 Ibid.

45 Ibid.

46 Ibid: 118.

47 Ibid: 9.

48 Government of Uganda (2017b). 
include the provision of water supply services for domestic and other uses. ${ }^{49}$ The Act specifically provides that the NWSC must develop the water and sewerage systems in urban centres and big national institutions. ${ }^{50}$ Inevitably, the NWSC operates within a limited scope of urban centres and state-owned institutions. Other provisions of the NWSC Act deal with the corporation's management, providing that it shall be managed as a commercially viable entity. ${ }^{51}$

The NEA establishes a framework that envisages that the National Environment Management Agency will work with districts in setting and implementing environmental goals. ${ }^{52}$ For instance, the NEA stipulates that the local government system shall on the advice of a district environment committee, appoint local environment committees whose functions include preparing a local environment work plan, consistent with a national environmental action plan. ${ }^{53}$

More than twenty years after the enactment of the 1995 Constitution, the institutional setup is still not delivering and is dogged by several contradictions that impede its ability to deliver desired reforms. On the one hand, decentralisation is endorsed; while on the other, a centralised approach is promoted. Consequently, it is plausible to argue that the institutionalised exclusion of citizens identified within Uganda's pre-1995 constitutional dispensation continues to inadvertently surface through the multitude of institutions that have varied mandates. ${ }^{54}$

One consequence of varied institutional mandates within the same sector relates to the cost of water and sanitation services. While the individual's autonomy to access water services through the NWSC is guaranteed, the use of water derived from the water authorities' supply infrastructure attracts charges/fees for service provision. ${ }^{55}$ Such charges have implications. First, the NWSC is allowed by law to index its water

49 Section 5(2)(b)(i) of the NWSC Act.

50 Section 5(2)(d) of the NWSC Act.

51 The NWSC has several institutional guidelines relating to the manner in which water supply will be managed. Some of these relate to water quality standards and a customer service charter. But these are non-enforceable standards which do not further a possibility for citizens to vindicate claims for a human right to water.

52 Section 14 of the NEA.

53 Section 14 and 16(2) of the NEA.

54 Prior to 1962, the NWSC served a few towns, which were predominantly occupied by Europeans and Asians.

55 See Section 32 of the Water Act. Fees charged to consumers of water services include: 1) monthly service charges; and 2) in case of disconnection, reconnection fees. See further Section 94 of the Water Act that enables the authority to fix rates and charges for the services it provides. Regulation 28(1), Water Supply Regulations 1999, determines that charges are payable within a period of 14 days from the date of receipt of notice. Charges may be assessed on the basis of quantity of water supplied, or any other manner approved by the Minister. According to Section 94(4) of the Water Act, a water authority is authorised to establish the minimum charges to be paid for water supplied, and the charges to be paid per unit of water supplied, albeit with the prior approval of the Minister. See further Section 5(2)(b) of the NWSC Act, that mandates the NWSC to set tariffs and charges. 
service rates to prevailing market prices. For instance, the Water Act (General Rates) Instrument determines that the rates payable are subject to annual indexation against the domestic price index, the exchange rate, the foreign price index and the electricity tariff. ${ }^{56}$ It is arguable that, even where water authorities set out to price water at an affordable rate, such annual indexation would negate affordability if it is accepted that other determining factors of the water price consistently rise sharply annually. ${ }^{57}$ Moreover, in other instances, the poor pay more for water services. ${ }^{58}$ The Ministry of Water and Environment's annual sector report ${ }^{59}$ highlights this challenge noting that an average tariff charged by private service providers was three times higher than the tariff charged for household connections. ${ }^{60}$

In semi-urban and rural areas, the nature of water use is distinct and covers multiple uses. Besides water requirements for basic human consumption and sanitation, many individuals need water for both livestock and crop farming. In many parts of Uganda, subsistence agriculture is practised. This means that the volume of water consumed may be much higher than those consumed in a typical urban household. Indeed, most rural households rely on the springs, wells, boreholes, valley dams and water harvesting from water bodies as a source of water for their livestock and crop farming. ${ }^{61}$ Subsequently, the matter of fees and their negative impact on the affordability of water appears to determine how far out of the urban setting the NWSC can extend its network. It is clearly difficult to extend the piped water supply system to areas where the community cannot afford the service, and would rather rely on natural sources.

While it must be acknowledged that some amount of control and regulation is required to manage and supply water services, the provisions in the NWSC Act appear to identify the collection of revenue and avoidance of loss, as the core functions of the institution. This approach is manifestly neo-liberal. While the NWSC has been planning to realise the goal of delivering water to all by 2040, it may face challenges because of its institutional structure and mandate. The mandate of the NWSC does not entirely lend itself to a rights-based approach to water and sanitation services' delivery needed for the realisation of the SDGs by 2040. This means that the ministry responsible for water must also continue to take on a larger role in supporting service delivery for rural-based consumers.

56 Regulation 3 of the Water Act (General Rates) Instrument, Statutory Instrument No. 30 of 2006.

57 In an interview with the NWSC-Kampala Water Legal Services Manager in September 2013, the author learned that at that time, the NWSC paid Uganda shillings 2 billion (equivalent to US $\$ 750,000$ ) each month towards electricity charges for supplying water within Kampala alone (The interview transcript is on file with author).

58 As of 2016, the average tariff at a public stand pipe of Ug.shs. 150/= per 20 litre container was three times higher than the tariff at household connections. Government of Uganda (2017b: 177).

59 Government of Uganda (2017b: 177).

60 Ibid.

61 Ibid: 6 . 
When the provisions of the Water Act and the NWSC Act are considered together, the conclusion is that the legal and institutional frameworks are presently inadequate to deliver water to all by 2040. To date, citizens still rely on self-help mechanisms to access water. Sometimes, rainwater is harvested during the rainy seasons and stored in large quantities; boreholes may be used; or an individual with a standing tap may sell water at a small premium. ${ }^{62}$ In some urban areas, mobile water trucks may sell water to locals, or a local entrepreneur may collect water from a spring and traverse the neighbourhood selling jerry cans from a bicycle. While these provide some relief to citizens, the methods appear unsustainable. At the district level, the local governments have been given conditional grants to develop water and sanitation facilities within each district. Due to the demand for water supply services, many of these are still being spent on developing and maintaining infrastructure within the towns and rural growth centres.

In addition, the trend seems to have shifted from a devolved to a more centralised system. Even though the 1995 Constitution envisaged devolving powers to local authorities, studies show that twenty years after the promulgation of the 1995 Constitution, local governments are still weak and lack the skills and know-how to effectively plan and execute suitable water and sanitation service delivery programs. ${ }^{63}$ As a result, the NWSC's proven success has led to an arrangement where local water and sanitation services are handed over to the NWSC for efficient management when they reach optimum capacity. With the growth of more towns, it remains to be seen whether the institutional advantages of a post-privatisation NWSC will be replicated at a larger scale if it takes over all the existing 111 local government supply schemes. The limitations of scaling up include inefficiency. Therefore, while it may present an example of a success story, the challenges of inefficiency that affect reliable access to water and sanitation services, may foster future tensions.

The underlying challenges related to poverty

Poverty is another enduring problem that affects the context in which water is delivered in Uganda. $70.3 \%$ of Uganda's population was reported to be multi-dimensionally poor in $2016 .{ }^{64}$ As in other developing countries where water is scarce, women and

62 The cost of tapping large amounts of rainwater still remain prohibitively high because of the high cost of safe reservoirs. For example to be able to set up a rain water harvesting system and store 40,000 litres of water in a plastic and easy to clean tank may cost up to USD 2,000.

63 Government of Uganda (2012: 3).

64 According to the 2016 Human Development Indicators profile for Uganda, the country ranked below the trends in sub-Saharan Africa. The indicators provide a composite measure of three dimensions: health, education and income. Uganda's HDI was 0.493, ranking 163 out of 187 countries with comparable data. In comparison the HDI of sub-Saharan Africa was 0.497. 
children in Uganda are burdened with collecting water. A large percentage of the population still spend significant amounts of their productive time walking long distances to collect water. ${ }^{65}$ To compound this, owing to the long distances travelled, even the water collected may end up contaminated due to unhygienic water handling and storage practices. ${ }^{66}$ This implies that there are still many citizens who need support in enhancing their enjoyment of the right to good quality water and whose social context ought to be taken into account when planning and implementing water delivery programs.

The development of water and sewerage infrastructure is a costly investment and is therefore categorised as an infrastructure project rather than as a social service. Funding for water and sewerage infrastructure development is therefore an essential determinant in how the state approaches water delivery services. In Uganda's case, water infrastructure has been funded through the World Bank, IFC, the European Union, DANIDA, the Austrian government and the African Development Bank, among others. Most of the funding is in the form of long-term development loans and grants. ${ }^{67}$ Where the funding is a loan, it has to be repaid, and a business case has to be made in order to acquire the loan. For instance, there must be an indication of the demand for the water services, which will eventually begin to pay off the loan. Where grants are given, there must be an indication of demand and willingness to pay for the services so that the grant facility is put to optimum use. Yet the majority of citizens who lack access to water and sanitation services are poor and unable to pay consistently for water services.

The governance system at the local authority level is weak and unable to mobilise revenues efficiently for the services. Even where the central government subsidises local governments to support infrastructure development, funding to the entire water and environment sector remains low, at $3 \%$ of the national budget, even as the population and its needs increase. ${ }^{68}$

While the state has made progress in enhancing access to water supply from an economic perspective, the underlying problems surrounding substantive enjoyment of the human right to water remain. ${ }^{69}$ Given that the poorest and most vulnerable may be

Sourced from <http://hdr.undp.org/sites/all/themes/hdr_theme/country-notes/UGA.pdf $>$ (accessed 23-3-2018).

65 Government of Uganda, Sector Performance Report (2017b:3) 70\% of citizens in rural parts of the country walk at least one kilometre to reach an improved water source. This implies that about $30 \%$ may walk a longer distance.

66 United Nations (2006: 61).

67 Government of Uganda (2017b: 26).

68 Government of Uganda (2016: 7 and 28).

69 Over the last 20 years, Uganda moved from implementing a Poverty Eradication Action Plan (PEAP I and PEAP II), which was intended to provide a framework for national planning; to a National Development Plan (NDP I and presently II). While the country is essentially still struggling to alleviate poverty, the NDP provides a more comprehensive agenda covering all areas likely to impede development. 
unable to compete for water in circumstances of scarcity, it seems that the state's initiatives may perpetuate the inequity existing in water delivery models. It would therefore seem that while Uganda does not suffer from water scarcity, the enjoyment of access to water is impeded by the weak water governance regime. This raises the question of whether approaching water delivery issues from a human rights paradigm may lead to a better enjoyment of water services by the entire population.

5 Opportunities: towards an environment and human rights-based approach to water and sanitation delivery

The notion that rights are a tool for social transformation is viewed with cynicism in some circles. ${ }^{70}$ It has, for instance, been argued that law, by design, protects and entrenches the interests of the few who have or control resources. Some have argued that the conceptualisation of human needs within the human rights framework only serves to legitimise the interests of the wealthy and effectively to maintain the status quo, given that there are often laws through which the poor are excluded from enjoying access to basic needs. ${ }^{71}$ Moreover, it has been argued that through the liberties that come along with rights' recognition, a rights framework prevents the redistribution of resources in any manner that would likely improve the social status of the poor and vulnerable. ${ }^{72}$ In short, the argument is that law serves the interests of those with power, and therefore the human rights model cannot improve the lived realities of the poor and vulnerable.

But these arguments have been countered and have mostly been found to be erroneous. Scholars arguing for the application of a rights-based approach within the domestic context advance the view that a rights-based approach empowers those who are poor and vulnerable to secure their freedom and entitlement to enjoy certain rights through direct claims made against the state. ${ }^{73}$ Within the context of access to water services, it is increasingly accepted that a rights-based approach can inform decisions in the climate change context. ${ }^{74}$ The approaches that have been recognised as being rights-based include participation, accountability, non-discrimination and equality, empowerment and legality. In 2015, the Ministry of Water and Environment undertook to incorporate a human right to water and sanitation among the indicators against which its performance should be measured. ${ }^{75}$

70 Tushnet (1984: 1363).

71 Ibid.

72 Ibid. See also Pieterse (2007).

73 O'Connell (2012: 4).

74 United Nations (2010: 3).

75 Government of Uganda (2017b: 6). 
During the course of 2013, the Ministry of Water and Environment initiated proposals for broad reforms to the country's water legislation. Although these proposals are yet to be implemented, it is clear that the need for reform is acknowledged. The proposals for reform have been motivated by the need to incorporate many of the developments in water resource management and water delivery that have taken place over the past 14 years. Since these proposals have not come into force, they are not yet applicable within the legal regime governing water. ${ }^{76}$ Nonetheless, two significant proposals should be mentioned, namely the draft National Water Policy ${ }^{77}$ and the draft Water (Amendment) Bill. ${ }^{78}$

The draft National Water Policy proposes six guiding principles for reformulating the domestic water supply policy. These are: to prioritise protection of the environment; to enhance participation of women in water service delivery; to strengthen communities to implement and sustain water and sanitation programs; to enhance financial viability of public utilities; and to ensure the allocation of public funds for water supply development activities in a manner that prioritises those segments of the population who are presently inadequately served or not served at all. ${ }^{79}$ The draft Policy appears to have considered a re-conceptualisation of water delivery in a manner that incorporates the human right to water and its implications for domestic water supply.

Within the draft Water (Amendment) Bill, the significant proposal is to extend the right to access water to include a clause to the effect that residents are entitled to access water through the use of rainwater harvesting techniques, such that an owner or occupier of land may construct any works for rainwater harvesting or for the recycling of used water for domestic purposes without having to seek approval or a permit from the water authority. ${ }^{80}$ While this may elaborate on an entitlement to use water, it also raises some challenges. An individualistic approach may subsequently affect water reservoirs in the wetlands and rivers where such rainwater would naturally drain into. This would ultimately reduce available shared water resources.

Whereas these proposals for reform are welcome, it appears that they will change little in terms of the substantive enjoyment of a human right to water and sanitation, to the extent that the scope of the right remains vague and the obligations attaching to the State for realising the right are absent. The proposals do not go far enough to articulate an enforceable right to water and sanitation.

In a nutshell, water delivery for most citizens in Uganda is effected by self-help mechanisms, with minimal state intervention, both within urban and rural areas. The

76 This information arose from a personal communication with an official with the Ministry of Water and Environment. Important to note is that neighbouring states such as Kenya (2016) and Tanzania (2009) have amended the relevant Water services legislation.

77 Proposed National Water Policy (draft of July 2013) 1, 29. On file with author.

78 Proposed Water (Amendment) Bill, Section 7A (draft of June 2013). On file with author.

79 Proposed National Water Policy (draft of July 2013) 1, 29. On file with author.

80 Proposed Water (Amendment) Bill, Section 7A (draft of June 2013). On file with author. 
term self-help implies that individuals take responsibility to ensure that water is available for their households. In many instances, citizens still depend on customary riparian rights to share water resources and their own geographic knowledge of the city or rural area to determine where and how to reach water resources and the use to which water should be put. As noted above, rainwater is harvested during the rainy seasons or boreholes are used when they are functional. For others, the state water supply system may reach their homes or schools to supply water at a charge. This shows that the majority of water delivery arrangements are unregulated and operate outside the national policy and legislative framework governing the use and distribution of water. It is therefore necessary to work towards a policy and legislative framework that applies to the majority of citizens.

In addition to these legislative proposals, experts in water resource management have encouraged a transition towards integrated water resources management. ${ }^{81}$ This would mean that the process of formulating and implementing management strategies for sustainable water resources development takes into consideration various dimensions and temporal interdependencies among natural processes and human and ecological water uses. This means that the knowledge required to protect and sustain these water resources would be drawn from various disciplines, including various disciplines within the law itself. This could bridge the gap between the law and practice.

Under the framework for integrated catchment-based water resource management, Uganda presently has five water management zones located in the central, eastern, western, northern and southern parts of the country. It aims to ensure that water extraction from catchment areas is coordinated to serve the surrounding areas.

Water user groups and associations, which are provided for within the Water Act, are a formidable mode of enhancing meaningful participation. The Water Act stipulates that: "A set of individuals or households may form a water user group and collectively plan and manage the point source water supply system in their area" ${ }^{82}$ In 2017, the Ministry of Water and Environment's Sector Performance Report ${ }^{83}$ indicated that $88 \%$ of rural areas and $72 \%$ of urban areas had actively functioning water and sanitation committees. The Sector Performance Report also indicated that many of these committees had included women in their membership. A 2014 study on the performance of water user associations, carried out by an independent organisation, found that water user associations performed poorly on administrative and accountability mechanisms, operation and maintenance. ${ }^{84}$ While the government's study indicates progress, the benefits of public participation in decision making within the realms of

81 Government of Uganda (2017b: 14).

82 Section 50(1) of the Water Act.

83 Government of Uganda (2017b: 162).

84 See $<$ https://www.ircwash.org/sites/default/files/2014_10_ts-uganda-pb_assessment_service_delivery_models.pdf $>$ (accessed 6-5-2018). 
environmental law and human rights may not have been adequately realised within the context of water and sanitation delivery institutions.

This chapter set out to critically explore the impact of the legislative and institutional frameworks on water and sanitation delivery within Uganda. It argues that the legislative and institutional frameworks significantly set the tone for the conceptualisation of water and sanitation as a commercial service rather than as both a human right and a natural resource. The chapter demonstrates that the legislation predominantly focuses on the preservation of water resources and provides little ground for realising a human right to water and sanitation as envisaged within international law and the general comments of the UNCESCR. Uganda has not harmonised the two frameworks.

Notably, the legislative framework creates a myriad of institutions but has not allowed for the strengthening of local governments to plan and execute water and sanitation delivery in a sustainable manner. The local governments consequently remain weak and unable to fulfil and promote a human rights-based approach to water and sanitation service delivery. While the current government statistics relating to the coverage of clean and safe water and sanitation are impressive, this has remained led by the central government. Actual access to water and sanitation services remains impeded by legislative requirements and a corporate institutional framework that venerates payment and enhancing revenues. For the more impoverished communities, the situation is dire as their demands for water cannot be met due to the costs of accessing water. The institutional limitations will continue to impede efforts to reach the SDG Goal 6 - to provide clean and safe water to all by 2030. There is a need for more meaningful public participation, decentralisation and catchment-based approaches that enhance water and sanitation services for Uganda's citizens.

\section{References}

Bates, BC, ZW Kundzewicz, S Wu \& JP Palutikof (2008) Climate change and water Technical Paper VI, International Panel on Climate Change.

Bourquain, K (2008) Fresh water access from a human rights perspective.

Government of Uganda (2012) Draft national local government capacity building policy.

Government of Uganda (2013) Joint water and environment sector strategic plan final programme document (2013-2018).

Government of Uganda (2016) The national development plan 2016/17-2021/22.

Government of Uganda (2017a) Water supply atlas, at <http://mwe.go.ug/index.php?option=com docman\&task $=$ cat_view\&gid=59\&Itemid $=55>($ accessed 10-1-2015).

Government of Uganda (2017b) Uganda water and environment sector performance report. 
Mpanga, MP (2015) Conceptualising, realising and enforcing a human right to water for Uganda: comparative perspectives $\mathrm{PhD}$ thesis, University of the Witwatersrand.

Mwebaza, R (2009) "Climate change and the international human rights framework in Africa" in R Mwebaza \& LJ Kotzé (eds) Environmental governance and climate change in Africa: legal perspectives 227-261.

Nabaho, L (2013) "Recentralization of local government chief administrative officers appointments in Uganda: implications for downward accountability" Commonwealth Journal of Local Governance 17-29.

Twinomugisha, B (2009) "Implications of climate change for the right to health in Uganda" in R Mwebaza \& LJ Kotzé (eds) Environmental governance and climate change in Africa: legal perspectives 267-268.

O'Connell, P (2012) Vindicating socio-economic rights international standards and comparative experiences.

Pieterse, M (2007) "Eating socioeconomic rights: the usefulness of rights talk in alleviating social hardship revisited" 29(3) Human Rights Quarterly 796-822.

Tushnet, M (1984) “An essay on rights” 62(8) Texas Law Review 1363-1403.

United Nations (2010) Climate change and the human rights to water and sanitation, at $<$ http://www2.ohchr.org/english/issues/water/iexpert/docs/ClimateChange_HRtWS.pdf $>$ (accessed: 15-3-2018).

United Nations (2006) $2^{\text {nd }}$ World water development report. 